\title{
Students' Views on the use of Augmented Reality Technology in Teaching Science
}

\author{
Gokhan Sontay, (Dr.) \\ Science Teacher, Ministry of National Education, Amasya, Turkey, \\ Orhan Karamustafaoğlu (Prof. Dr.) \\ Amasya University, Faculty of Education, Amasya, Turkey,
}

URL:http://dx.doi.org/10.19044/ejes.v8no4a1

Submitted:15 May 2021

Accepted: 25 August 2021

Published: 31 December 2021
Copyright 2021 Author(s)

Under Creative Commons BY-NC-ND

4.0 OPEN ACCES

\section{Abstract:}

As a result of recent technological developments, many mobile applications used in the educational environments have emerged. One of these applications is the augmented reality technology used in smartphones and tablets. Many augmented reality applications are now prepared with 4Dtechnology and are employed to transform virtual environments into real life situations. In this study, we examined the views of 6th-grade students about using augmented reality technology in teaching science. Designed as a phenomenological research from the qualitative research methods, this study was conducted with nine 6th-grade volunteer students studying in a secondary school in the district of Göynücek in Amasya Province during the 2017-2018 academic year. The data were collected through interviews, using a semistructured form. We analyzed the data set, by applying descriptive analysis method using NVivo 9 program. Categories emerged from the student views. We modeled the qualitative data in terms of these categories. Based on the research findings it was concluded that the augmented reality activities carried out provided permanent learning about the systems in our body and increased positive attitudes and interests towards the lessons, according to the students' opinions. We concluded that the science teaching with the use of augmented reality technology will provide positive learning outcomes on students. Further, teachers should receive and be provided with professional development on augmented reality to be able to use it more efficiently. This study is expected to contribute to researchers and practitioners in the future.

Key Words: Augmented reality technology, Science teaching, Student views. 


\section{Introduction:}

To deal with the increasing amount of information which has been becoming more complex today, new inquiries are needed since developments in technology offer new educational opportunities and innovations to teaching practices (Sumadio \& Rambli, 2010). Recently, the augmented reality technology (ART) has come to the fore as an innovation in teaching. Augmented reality is the live, direct or indirect physical view of the real physical environment created by enriching it with sound, image, graphics and location data produced by computers or mobile devices (Arslan \& Elibol, 2015).

Augmented reality facilitates to understand information that is not fully comprehended through senses and cognitive processes under normal circumstances (Azuma, 1997; Kaufmann \& Schmalstieg, 2003; Klopfer \& Squire, 2008). ART is mainly used in the application of dangerous experiments and activities in the teaching process and in the teaching of objects which are invisible or difficult to be obtained (Wu, Lee, Chang, \& Liang, 2013). One of the most important goals of increased technology, which is becoming widespread and used in education, is to enhance the retention of knowledge in teaching (Huang, Chen, \& Chou, 2016).

By combining education systems and technology, sensory organs can be used more in teaching (Daşdemir, Cengiz, Uzoğlu, \& Bozdoğan, 2012). The more sensory organs are stimulated and better activated in the learning environment, the more effective and permanent learning is achieved (Çepni, Ayas, Ekiz \& Aky1ldız, 2010). Augmented reality applications activate the sensory organs (Lee, 2012). Thus, the subjects that students have difficulty in learning and the properties of objects difficult to access can be learned more easily while teaching. Moreover, the objects with abstract features that cannot be seen with naked eye in the real world can be modeled in three dimensions and therefore can be presented as more tangible concepts.

Augmented reality applications used in mobile applications contribute greatly to today's learning environments (Ibáñez, Di Serio, Villaran \& Kloos, 2016; Lim \& Lim, 2020; Özdemir, 2017; Zhang, Sung, Hou \& Chang, 2014). The 3-D use of visual objects in the teaching process with augmented reality applications attracts students ' attention and motivates them to participate in the lessons (Avila-Garzon, Bacca-Acosta, Kinshuk, Duarte, \& Betancourt, 2021; Kerawalla, Luckin, Selijefot \& Woolard, 2006; Khan, Johnston, \& Ophoff, 2019). Student views must be expanded and further enhanced on the use of ART in educational settings. Evaluating applications related to augmented reality through the eyes of the student is very important for determining the ideal use of augmented reality in educational environments. Hence, students view on the positive aspects of augmented reality applications, opportunities, and challenges will provide important evidence on the use of augmented reality in schools. Thanks to this, it will be possible to 
have an idea of the effects of augmented reality applications on the teaching process.

In this study, we intended to reveal the views of 6th-grade students about the use of augmented reality technology in science teaching. In this sense, these research questions guided this study:

RQ1. What are the students' general views on ART?

RQ2. What are the positive or negative aspects of augmented reality applications according to the students?

RQ3. What are the students' views about the impact of augmented reality application in science class and the use of ART on other science subjects?

\section{Method}

\section{Research Model}

Designed as a qualitative research in its nature, this study is a phenomenological inquiry into students' views on using ART in science teaching. In the phenomenology design, individuals' perceptions of a phenomenon and the meanings they attribute to these phenomena are sought to be determined, and the source of the study is individuals who experience and reflect the phenomenon under investigation (Creswell, 2013). In this sense, the design of this study was determined as phenomenology since secondary school 6th-grade students can be seen as individuals who live and reflect the application of augmented reality in their lessons.

\section{Participants}

We recruited a total of 9 6th-grade students studying in a secondary school in Göynücek district of Amasya province in the 2017-2018 academic year. Due to the ethical considerations and the anonymity as well as the confidentiality, the participants were randomly coded as S1, S2, S3, ..

\section{Data collection}

Data were collected through a semi-structured interview form prepared by the researchers. In the preparation of the interview form, the opinions of a faculty member specialized in science education and three science teachers were consulted. The interview form was finalized according to the feedback from the expert opinions. The interview form used in the study is presented as an Annex to the present paper.

The interview questions were asked by conducting individual interviews with each of the participating students. In total, 9 individual indepth interviews (IDIs) were conducted. The answers to each question asked during the interview were recorded by the interviewers with the help of paperand-pencil forms. All individual interviews were then transcribed. All these transcripts were retained by the researchers. The IDIs lasted approximately 20 - 
25 min. until the information from an interviewee reached saturation. During the interviews, interviewer had a neutral position.

The data were collected after the subject of systems and organs in our body, which is included in the science course, was carried out. The application process was as follows:

- First, science cards containing ART related to the systems and organs in our body were pur-chased online.

- Information was given to the students about the ART by the teacher (first author)

- "Anatomy 4D" program, which is an augmented reality application, was installed on teachers 'and students' tablets. Later downloaded programs were opened in tablets.

- After the program opened, the science cards and the program were matched according to the instructions of the program.

- In this way, some concepts that are physically difficult to reach were examined in the classroom environment.

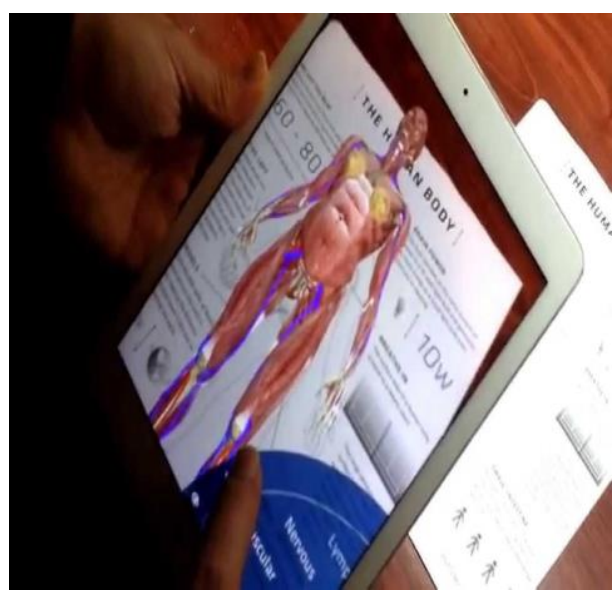

Figure 1. Example of augmented reality visual for the muscle system

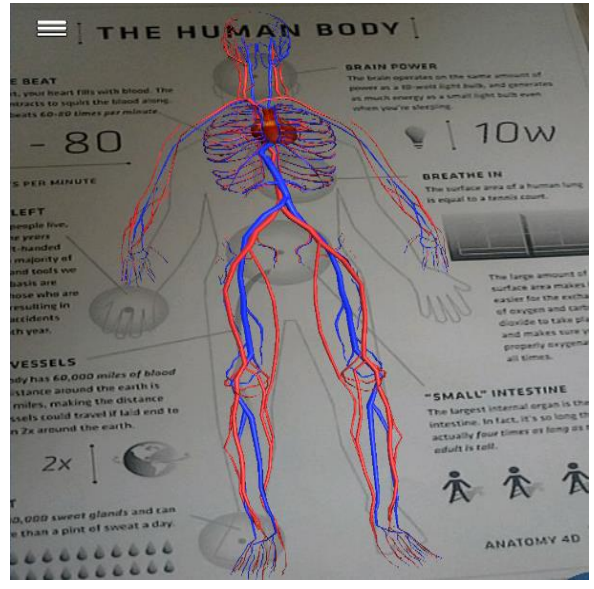

Figure 2. Example of augmented reality visual for the circulatory system 


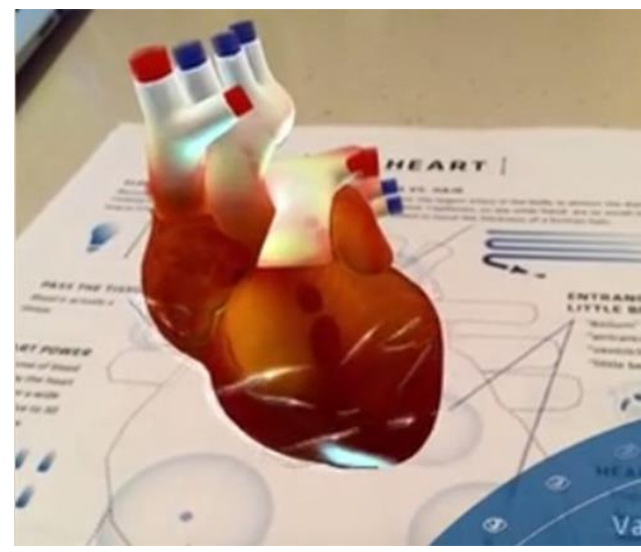

Figure 3. Example of augmented reality visual for the circulatory system and heart

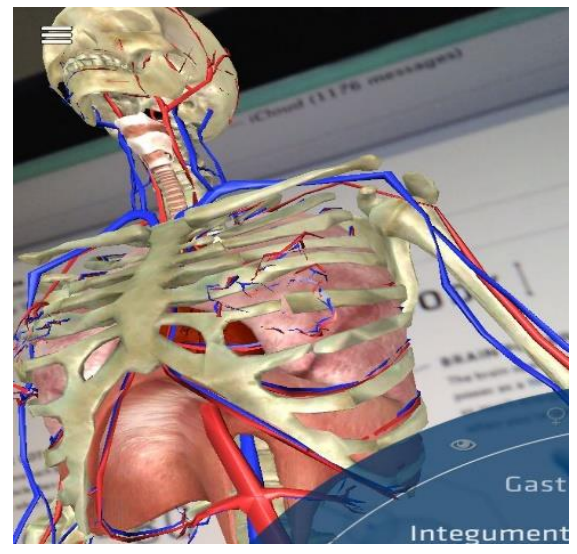

Figure 4. Example of augmented reality visual for skeletal and muscular system

\section{Data Analysis}

The data of the research were analyzed by descriptive analysis method using NVivo 9.0 program. Descriptive analysis is the arrangement of the data obtained according to predetermined categories, the definition and interpretation of the findings. In the descriptive analysis method, the existing situations are summarized, and sample citations are included (Özmen \& Karamustafaoğlu, 2019). Following the analysis, five categories emerged as follows: General views about augmented reality, positive aspects of augmented reality application, negative aspects of augmented reality application, its effect on science lesson and its use in other subjects. The categories were modeled to facilitate the comprehension of the results under these categories. The obtained data while creating the categories were coded independently by two researchers to ensure the validity and reliability of the research. A value of .94 was obtained by determining and calculating the codes with which there was a consensus and disagreement. According to Miles and Huberman (1994), it is sufficient to accept the research as reliable if the calculated reliability value is above .70 .

\section{Findings}

In this section, the codes belonging to the categories determined as a result of the analysis of the data are presented together with the models. Student views on the category of "General Views on Augmented Reality" are presented in Figure 5. 


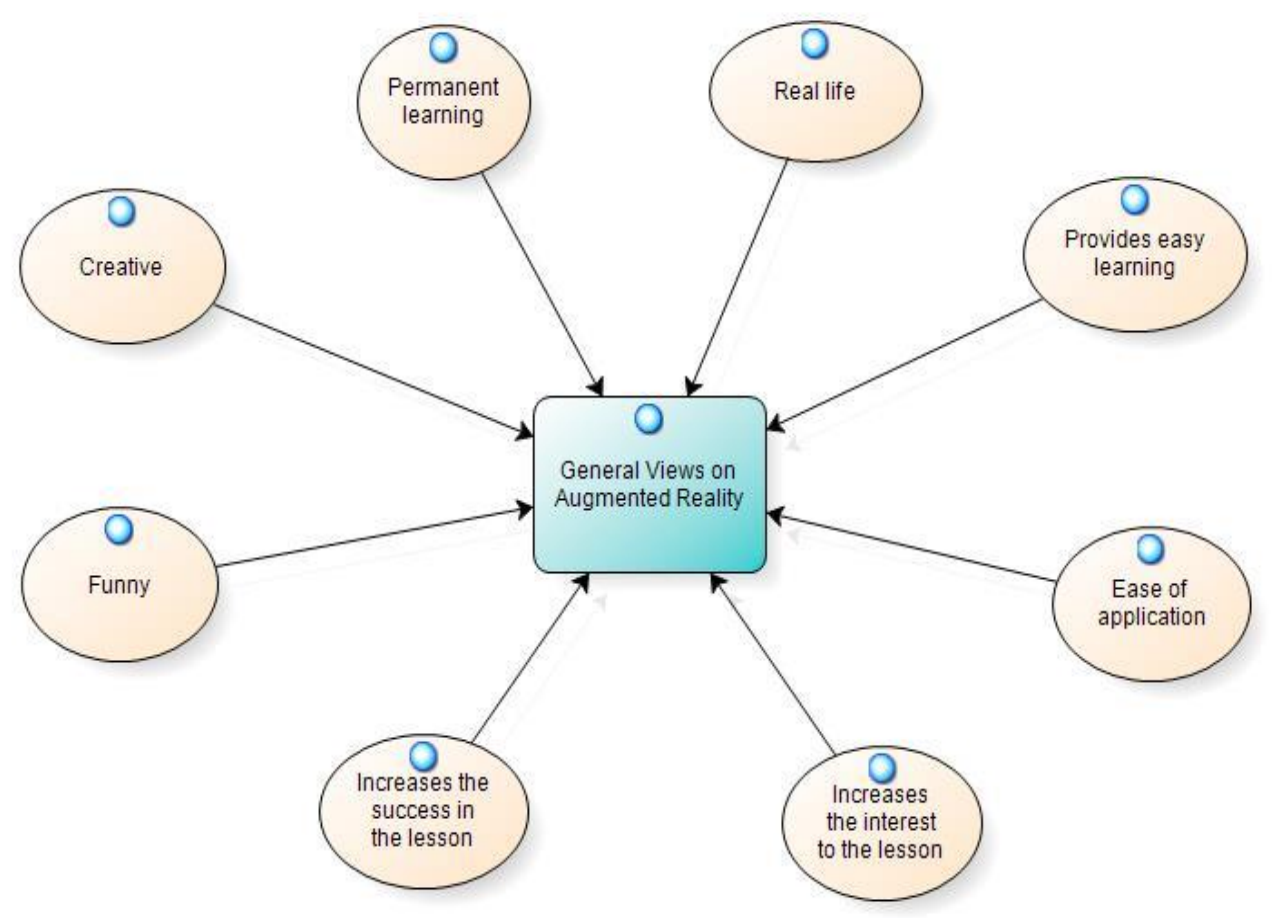

Figure 5. Modeling of "general views on augmented reality" category Some of the literal expressions taken from the views of students for this category are presented below.

“... It had a positive effect on my success in science lessons. It increased my interest in the lesson... ( $\left.S_{2}\right)$ "

“... I had lots of fun during the activities. I learned the subject better... $\left(S_{4}\right) "$

“... I learned the systems and structures in our body more easily and permanently... $\left(S_{5}\right) "$

Students' views belonging to the category of "The Positive Aspects of Augmented Reality Application" are presented in Figure 6. 


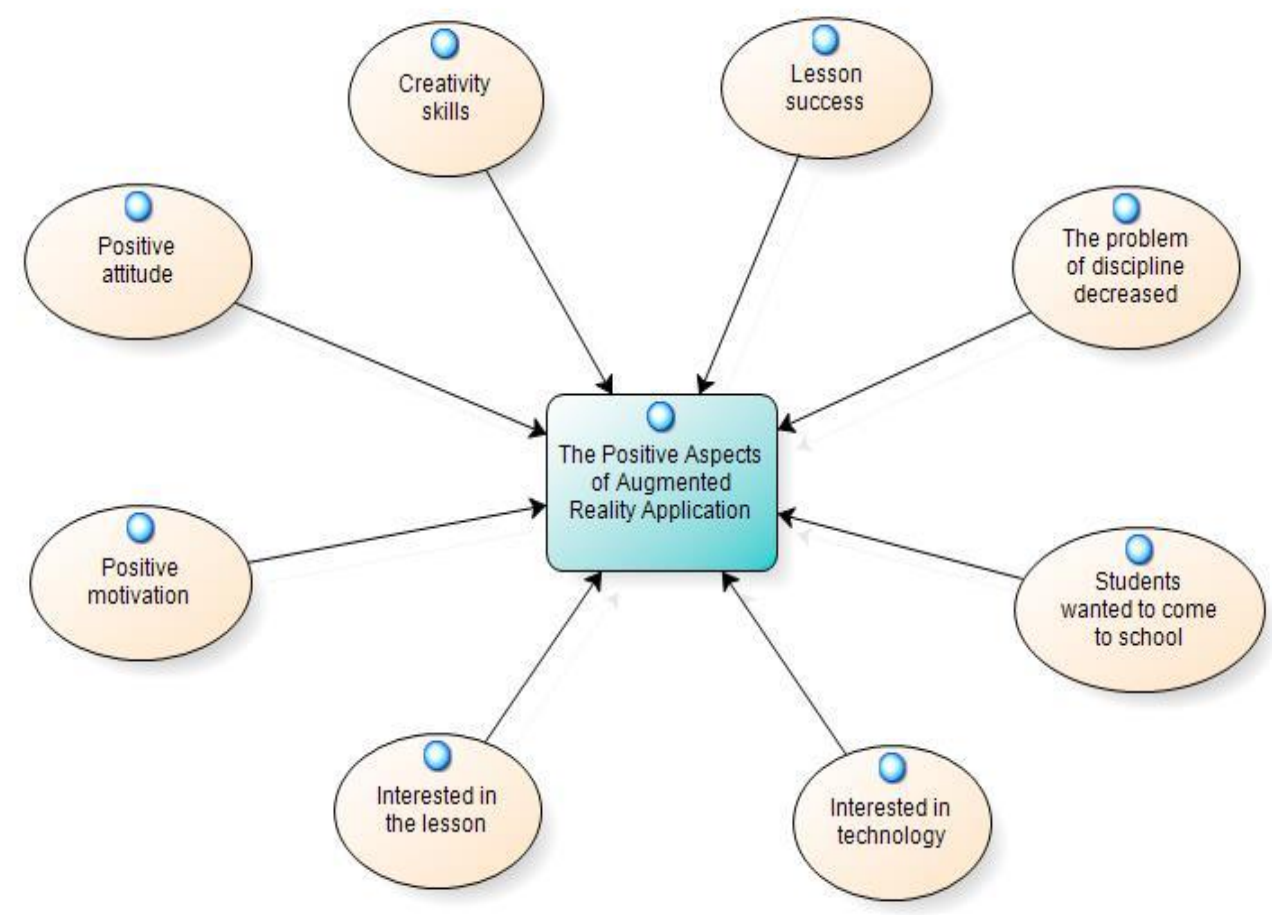

Figure 6. Modeling of "the positive aspects of augmented reality application" category

Some of the literal expressions taken from the views of students for this category are presented below.

"...Augmented reality activities positively affected my motivation for the lesson ...( $\left(S_{1}\right)$ ")

"...Ifocused better on the subject in classes. Throughout the augmented reality app, the class became quieter... ( $\left.S_{3}\right)$ "

"...The activities further improved my creativity ... $\left(S_{6}\right)$ "

Students' views belonging to the category of "The Negative Aspects of Augmented Reality Application" are presented in Figure 7. 


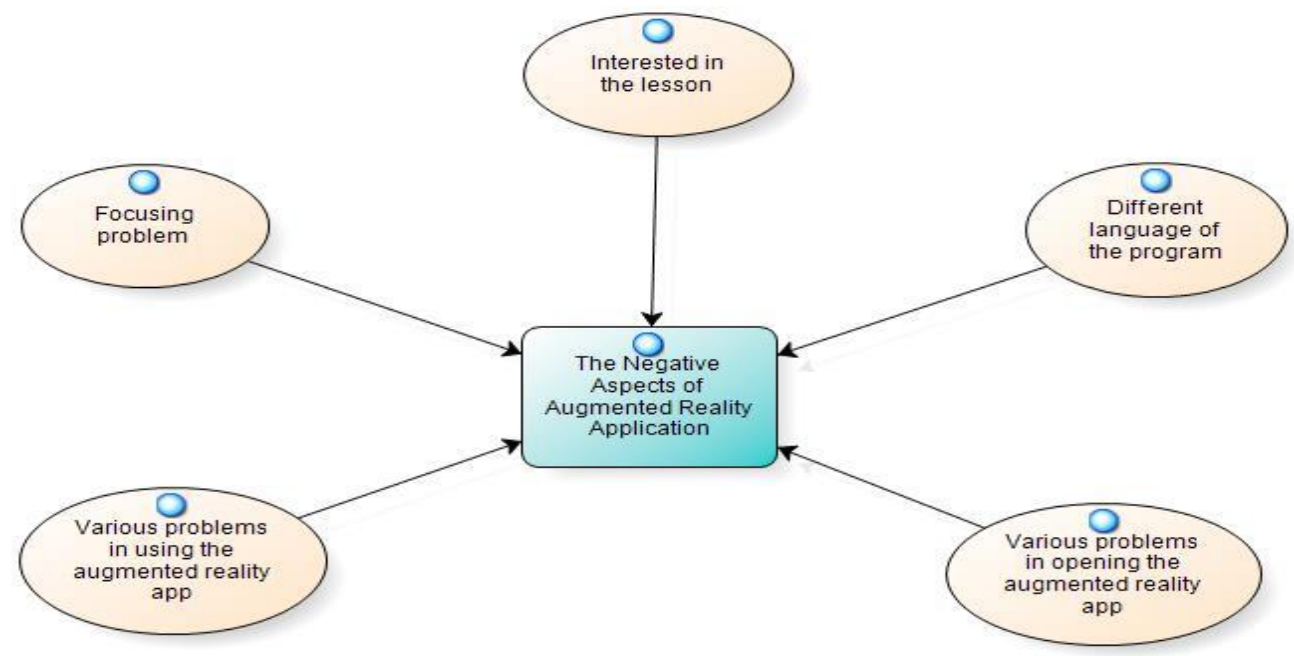

Figure 7. Modeling of "the negative aspects of augmented reality application" category

Some of the literal expressions taken from the views of students for this category are presented below.

“... Sometimes I got distracted. I could not focus on the subject... ( $\left.S_{7}\right)$

"... The program sometimes opened late, eee ... sometimes froze... $\left(S_{8}\right) "$

"... At times I could not control the augmented reality app. It took me a while to learn the program... $\left(S_{9}\right)$ "

Student views on the category of "Effect on Science Lesson" are presented in Figure 8.

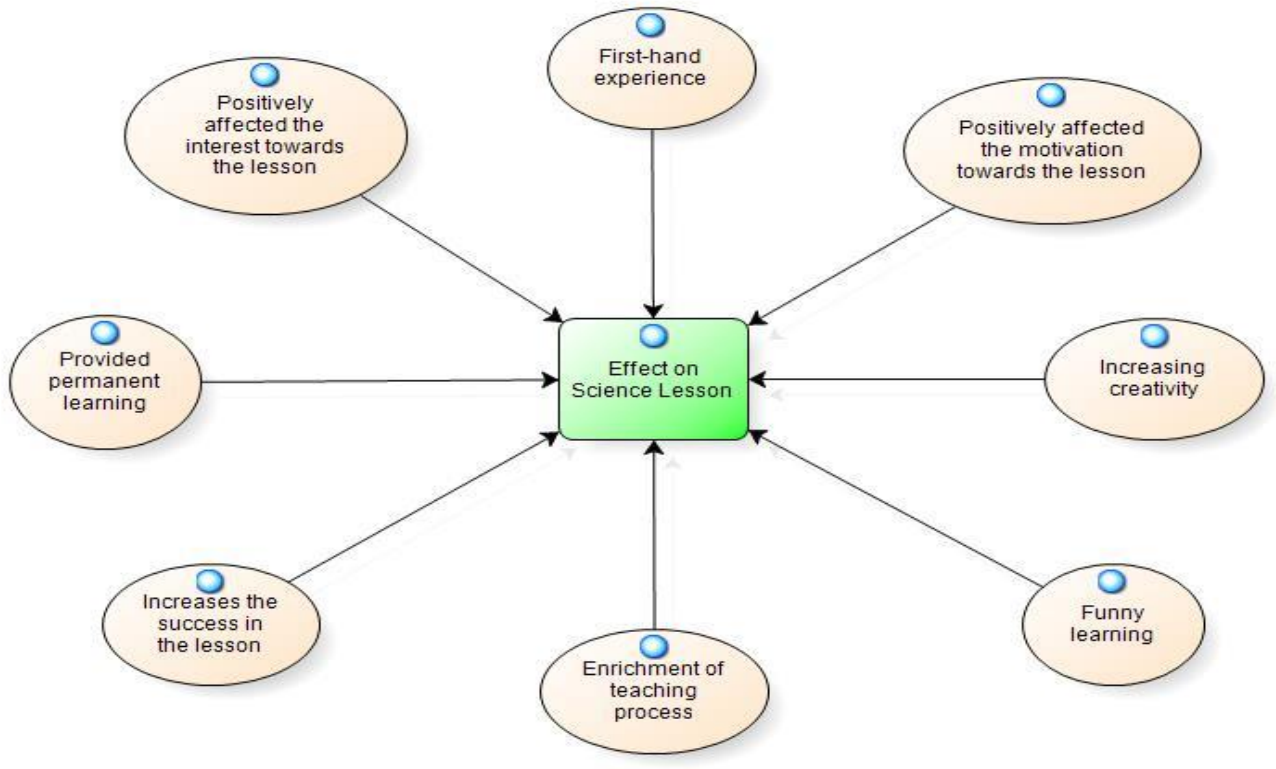

Figure 8. Modeling of " effect on science lesson" category 
Some of the literal expressions taken from the views of students for this category are presented below.

"... I saw the pictures in the textbook live. I understood the structures and organs of our body better... I, henceforth, have a better understanding the lessons better thanks to the augmented reality app $\left(S_{5}\right)$ "

"... The activities were very appealing. I am interest in science lesson increased ... $\left(S_{6}\right)^{\prime \prime}$

"...I think the information I read has become permanent. Because I did not understand much about the respiratory and circulatory systems. Due to $A R T$, I have a better understanding of places that are not understood... $\left(S_{7}\right)$ ")

Student views on the category of "Use in Other Science Subjects" are presented in Figure 9.

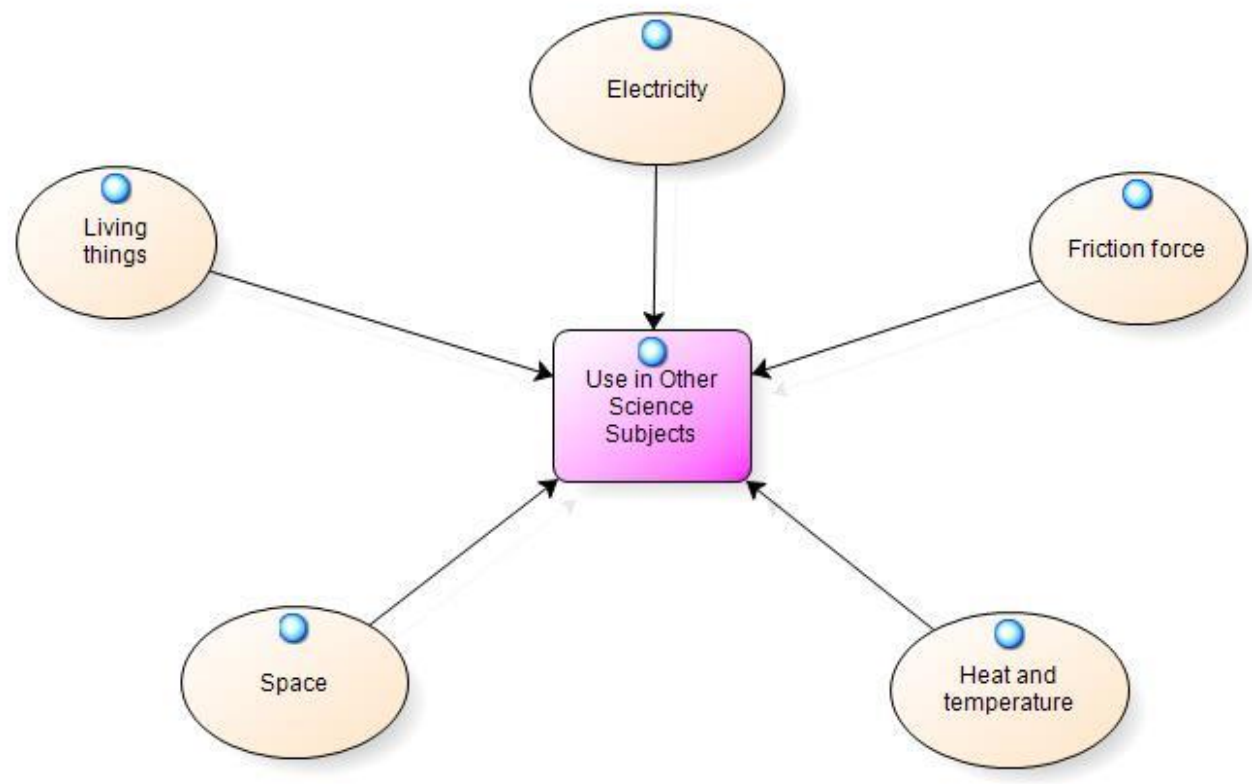

Figure 9. Modeling of " use in other science subjects" category

Some of the literal expressions taken from the views of students for this category are presented below. $\left(S_{2}\right)^{\prime \prime}$

"... I think it can be used in space subjects as space is a curious topic...

“... The subject of 'heat and temperature' is a difficult issue for me. Augmented reality can be used in this regard... ( $\left.S_{4}\right)$ "

"... The friction force topic seems very difficult to me. An augmented reality activity can be done to learn this subject more easily... ( $\left.S_{7}\right)$ "

\section{Result and Discussion}

This phenomenological inquiry into the student views on ART using in science teaching has pro-vided different categories. In this sense, upon 
analyzing the views of the students about the use of augmented reality app on the "Systems in Our Body" subject in the science course, five categories emerged. The findings obtained about the specified categories are discussed in this section.

In this study, which students' views on ART were examined, students generally stated that augmented reality is fun and creative, provides easy learning, permanent learning, ease of application and real life, and increases the interest and success in the lesson. Based on these findings, we concluded that students generally gave positive opinions about augmented reality. These results of this present study corroborate with previous literature. Students can better grasp the subjects related to the lessons thanks to the augmented reality technology (Huang, Chen, \& Chou, 2016). Rizov and Rizova (2015) stated that augmented reality increases students' interest in the lesson and that the learning content is easier to understand.

Examining the students' opinions about the positive aspects of the augmented reality application, we found that positive motivation, positive attitude, interest in the lesson, lesson success and creativity skills increased; It was stated that the problem of discipline decreased, students wanted to come to school and they were interested in technology. According to these findings, it was observed that the activities related to augmented reality affected the affective characteristics of the students in a more positive way. In addition, it was understood that it increased the success in science class according to some students. Previous literature has documented evidence in that augmented reality increases students' motivation, attitude and interest towards the course (Di Serio, Ibáñez, \& Kloos, 2012; Dunleavy, Dede, \& Mitchell, 2009; Sumadi \& Rambli, 2010; Sirakaya \& Alsancak Sirakaya, 2020).

When students view about the negative aspects of the augmented reality application were examined, the students stated that they had various problems in opening and using the augmented reality app downloaded to the tablet. In addition, some students stated that they could not fully focus on the program and they encountered some problems such as the language of the program is in foreign language. In this context, it can be thought that students need guidance teachers while using the program, and the guidance teachers should explain the augmented reality program to the students in detail before using the program. Durak and Karaoğlan Y1lmaz (2019) stated that students had difficulty using the augmented reality pro-gram in lessons. Timur and Özdemir (2018) stated that teachers should receive training to use ART efficiently. Therefore, it can be thought that to eliminate the difficulties experienced by the students, the practices of guidance teachers regarding augmented reality should be better.

The students stated that the augmented reality app increased the success towards the science course, provided permanent learning and positively affected the interest and motivation towards the course. When the 
studies on ART were examined, it was emphasized in many studies that it increased the success of students in science courses (Chiang, Yang \& Hwang, 2014; Singhal, Bagga, Goyal, \& Saxena, 2012; Subhashini, Siddiqua, Keerthana, \& Pavani, 2020; Toledo-Morales \& Sanchez-Garcia, 2018; Wojciechowski \& Cellary 2013). Pérez-López and Contero (2013) expressed that ART increased the academic achievement of middle school students regarding 'systems in our bodies' subject. It has been stated that augmented reality is effective in eliminating misconceptions experienced in lessons and increasing academic success (Alper, Oztaş, Atun, Cinar, \& Moyenga, 2021; Enyedy, Danish, Delacruz, \& Kumar, 2012).

The students uttered that ART could be used in the subjects of space, living things, electricity, friction force, heat, and temperature. When the literature is investigated, it is seen that research have been carried out on ART in the subjects of space (Buluş Kırıkkaya \& Şentürk, 2018), electricity (Akbaş \& Güngör, 2017), living things (İzgi Onbaş111, 2018), friction force (Enyedy, Danish, Delacruz \& Kumar, 2012). However, no research has been found on augmented reality on heat and temperature.

\section{Conclusion and Recommendations}

As a result, 6th grade students agree that the ART will generally increase both motivation, attitude and interest towards the lessons and provide permanent learning about the 'systems and organs in our body' of the science lesson. However, some students had problems using ART. According to the findings of this and similar studies, it is thought that the ART can be used actively in all lessons in the following years.

Among the strengths of this study are that it is a current issue in education, using an appropriate assessment tool, being related to a technological application that attracts students' attention, and containing important findings for the conduct of the lessons. On the other hand, the weakness of the study is that it was conducted with 9 students and only 6th grade students and was limited to qualitative data. made:

Based on the results of the research, the following suggestions can be

- $\quad$ Augmented reality apps can be prepared for subjects that students have difficulties such as electricity, friction force, heat and temperature.

- In-service training on ART can be provided to teachers to use augmented reality apps more actively in lessons.

- It can be ensured that ART is integrated into science curricula.

- A similar study can be done in a different study/subject area and/or by adopting a different methodological approach.

- A similar research can be done based on adopting a theory such as the Theory of Change within the framework of a qualitative approach. 


\section{References}

Akbaş, M. F., \& Güngör, C. (2017). A survey on marker-based tracking systems in augmented reality and design of multi-layer marker model. Journal of Science and Engineering, 19(56), 599-619.

Alper, A., Oztaş, E. S., Atun, H., Cinar, D., \& Moyenga, M. (2021). A systematic literature review towards the research of game-based learning with augmented reality. International Journal of Technology in Education and Science, 5(2), 224-244.

Arslan, A., \& Elibol, M. (2015). Analysis of educational augmented reality applications: The case of Android operating system. International Journal of Human Sciences, 12(2), 1792-1817.

Avila-Garzon, C., Bacca-Acosta, J., Kinshuk, Duarte, J., \& Betancourt, J. (2021). Augmented reality in education: an overview of twenty-five years of research. Contemporary Educational Technology, 13(3), 1-29.

Azuma, R. T. (1997). A survey of augmented reality. Presence: Teleoperators and Virtual Environments, 6(4), 355-385.

Buluş Kırıkkaya, E., \& Şentürk, M. (2018). The 1mpact of using augmented reality technology in the solar system and beyond unit on the academic achievement of the students. Kastamonu Education Journal, 26(1), 181-189.

Chiang, T. H. C., Yang, S. J. H., \& Hwang, G. J. (2014). An Augmented reality-based mobile learning system to improve students' learning achievements and motivations in natural science inquiry activities. Educational Technology \& Society, 17(4), 352-365.

Creswell, J. W. (2013). Qualitative inquiry and research design: Choosing among five approaches (Third edition). New York: Sage.

Çepni, S., Ayas, A., Ekiz, D., \& Aky1ldı,, S. (2010). Öğretim ilke ve yöntemleri. Trabzon: Celepler Matbaacılik.

Daşdemir, İ., Cengiz, E., Uzoğlu, M., \& Bozdoğan, A. E. (2012). Examination of science teachers' opinions related to tablet pcs using in science and technology courses. Mustafa Kemal University Journal of Social Sciences Institute, 9(20), 495-511.

Di Serio, Á., Ibáñez, M. B., \& Kloos, C. D. (2012). Impact of an augmented reality system on students' motivation for a visual art course. Computers \& Education, 68, 586-596.

Durak, A., \& Karaoğlan Yılmaz, F., G. (2019). Opinions of secondary school students' on educational practices of augmented reality. Bolu Abant Izzet Baysal University Journal of Faculty of Education, 19(2), 468-481.

Dunleavy, M., Dede, C., \& Mitchell, R. (2009). Affordances and limitations of immersive participatory augmented reality simulations for teaching and learning. Journal of Science Education and Technology, 18(1), 7-22.

Enyedy, N., Danish, J. A., Delacruz, G., \& Kumar, M. (2012). Learning physics through play in an augmented reality environment. International Journal of Computer-Supported Collaborative Learning, 7, 347-378. 
Huang, T. C., Chen, C. C., \& Chou, Y. W. (2016). Animating eco-education: To see, feel, and discover in an augmented reality-based experiential learning environment. Computers \& Education, 96, 72-82.

İzgi Onbaş11, Ü. (2018). The effect of augmented reality practices on the attitudes of primary school students towards augmented reality practices and science motivation. Ege Journal of Education, 19(1), 320-337.

Ibáñez, M. B., Di Serio, A., Villaran, D., \& Kloos, C. D. (2016). Support for Augmented Reality Simulation Systems: The Effects of Scaffolding on Learning Outcomes and Behavior Patterns. IEEE Transactions on Learning Technologies, 9(1), 46-56.

Kaufmann, H., \& Schmalstieg, D. (2003). Mathematics and geometry education with collaborative augmented reality. Computers \& Graphics, 27(3), 339-345.

Kerawalla, L., Luckin, R., Selijefot, S., \& Woolard, A. (2006). Making it real: Exploring the potential of augmented reality for teaching primary school science. Virtual Reality, 10(3-4), 163-174.

Khan, T., Johnston, K., \& Ophoff, J. (2019). The Impact of an Augmented Reality Application on Learning Motivation of Students. Advances in HumanComputer Interaction, 2, 1-14.

Klopfer, E., \& Squire, K. (2008). Environmental detectives: The development of an augmented reality platform for environmental simulations. Education Technology Research and Development, 56(2), 203-228.

Lee, K. (2012). Augmented reality in education and training. TechTrends, 56(2), 13-21.

Lim, K. Y. T., \& Lim, R. (2020). Semiotics, memory and augmented reality: History education with learner-generated augmentation. British Journal of Educational Technology, 51(3), 673-691.

Miles, M. B., \& Huberman, A. M., (1994). Qualitative data analysis: a sourcebook of new methods. London: SAGE.

Özdemir, M. (2017). Educational Augmented Reality (AR) Applications and Development Process. Mobile Technologies and Augmented Reality in Open Education (p. 26-53). IGI Global.

Özmen, H., \& Karamustafaoğlu, O. (Ed.) (2019). Eğitimde araştırma yöntemleri. Ankara: Pegem Akademi.

Pérez-López, D., \& Contero, M. (2013). Delivering educational multimedia contents through an augmented reality application: A case study on its impact on knowledge acquisition and retention. Turkish Online Journal of Educational Technology, 12(4), 19-28.

Rizov, T., \& Rizova, E. D. (2015). Augmented reality as a teaching tool in higher education. International Journal of Cognitive Research in Science, Engineering and Education, 3(1), 7-15. 
Singhal, S., Bagga, S., Goyal, P., \& Saxena, V. (2012). Augmented chemistry: Interactive education system. International Journal of Computer Applications, 49(15), 1-5.

Sirakaya, M., \& Alsancak Sirakaya, D. (2020). Augmented reality in STEM education: a systematic review. Interactive Learning Environments, 1-14.

Subhashini, P., Siddiqua, R., Keerthana, A., \& Pavani, P. (2020). Augmented Reality in Education. Journal of Information Technology and Digital World, 2(4), 221-227.

Sumadio, D. D., \& Rambli, D. R. A. (2010). Preliminary evaluation on user acceptance of the augmented reality use for education. Second International Conference on Computer Engineering and Applications (ICCEA), 2010 Second International Conference, 2, 461-465.

Timur, B., \& Özdemir, M. (2018). Teachers' views on the use of augmented reality environments in science education. Journal of Turkish Education Sciences, 6(10), 62-75.

Toledo-Morales, P., \& Sanchez-Garcia, J. M. (2018). Use of augmented reality in social sciences as educational research. Turkish Online Journal of Distance Education, 19(3), 38-52.

Wojciechowski, R., \& Cellary, W. (2013). Evaluation of learners' attitude toward learning in ARIES augmented reality environments. Computers \& Education, 68, 570-585.

Wu, H. K., Lee, S. W. Y., Chang, H. Y., \& Liang, J. C. (2013). Current status, opportunities and challenges of augmented reality in education. Computers \& Education, 62, 41-49.

Zhang, J., Sung, Y. T., Hou, H. T., \& Chang, K. E. (2014). The development and evaluation of an augmented reality-based armillary sphere for astronomical observation instruction. Computers \& Education, 73, 178-188.

\section{Annex: Interview Form}

Semi-Structured Interview Questions for Students

1. Please tell me if you have ever heard of augmented reality concept? What do you think about the augmented reality technology / application? Can you explain?

2. What could be the positive aspects of augmented reality application? How would you specify them?

3. What could be the negative aspects of augmented reality application? How would you specify them?

4. In your experience, what effect did the augmented reality application have on the science lesson? Can you explain?

5. In what other science subjects would you like the augmented reality application to be used? Can you explain along with the reasons? 